\title{
PROFESSIONAL DEVELOPMENT IN FOSTERING SELF-DIRECTED LEARNING IN GERMAN SECOND ADDITIONAL LANGUAGE TEACHERS
}

\author{
Gerda-Elisabeth Wittmann \& Jako Olivier \\ Research Unit Self-Directed Learning, Faculty of Education, North-West University
}

\begin{abstract}
Teaching is a value-laden profession, and certain demands regarding lifelong learning are put on teachers worldwide. Requirements for entry-level qualifications and professional development of South African teachers are stipulated in the National Qualifications Framework Act (67/2008): Revised policy on the minimum requirements for teacher education qualifications (DHET, 2015) and the CPTD Management System Handbook of the South African Council for Educators (SACE, 2013). However, teachers in general, and German Second Additional Language (SAL) teachers in particular, struggle to meet these requirements. In line with international teacher development tendencies, this article recommends for a shift in teacher professional development programmes towards a more participant-centred approach. Theories of self-directed learning (SDL) are considered, and it is recommended that teacher professional development programmes focus on fostering the characteristics of SDL in South African teachers (especially German SAL teachers), which would enable these teachers to be active participants in their learning. The article strives to motivate the need for a professional development programme fostering SDL to support the existing developmental shortcomings. Recommendations are made on how SDL can be sensibly fostered in teacher professional development programmes in order to enable teachers to become self-directed learners. Practical recommendations are also made on how teachers can be empowered to become self-directed learners.
\end{abstract}

Keywords: German Second Additional Language (SAL), self-directed learning, teacher professional development, life-long learning

\section{INTRODUCTION}

Teaching is a value-laden profession (Hong, 2012: 432) in which certain demands have to be met while operating under suboptimal conditions (Modisaotsile, 2012: 1). While research has been done on the shortcomings of the South African schooling system (Lam et al., 2011; Yamauchi, 2011; Spaull, 2013b; Spaull, 2013a) and on the expectations placed on teachers (Gabela, 2004), few solutions to teachers' perceived shortcomings and their developmental needs have been offered to date (Minott, 2010; Ono \& Ferreira, 2010:59).

This article adheres to Coldwell's (2017: 189) rather broad definition of teacher professional development as 'formal and informal support and activities that are designed to help teachers develop as professionals. This includes taught courses and in-school training, as well as activities such as coaching, mentoring, self-study and action research.' While Coldwell does 
not directly refer to self-directed learning (SDL), many of the aspects of teacher professional development he mentions do correlate with SDL, as part of which, according to Mentz (2014), the facilitator ${ }^{i}$ designs and uses instructional strategies to enable participants to direct their own learning. Coldwell's definition can be supplemented by the view of Minott (2010: 325), who stresses the developmental aspect, thereby defining teacher professional development as an ongoing process that ensures teachers have the practical and work-related knowledge to continuously function in their designated roles as teachers. The professional development of teachers and the role that teacher educators play did not receive much research attention in the past (Murray, 2008; Berry, 2009). This situation is ascribed to the fact that teaching about teaching was for a long time not regarded as a specialised academic expertise (Berry, 2009: 305), sometimes even being positioned as 'semi-academics' (Murray, 2008: 18)

More recently, teacher professional development has been studied in various different ways (Coldwell, 2017; Smith, 2017b). Research usually focuses on how teachers learn, how they learn to improve their learning, and how they transform their skills and knowledge into practice to offer their own learners an improved educational experience (Avalos, 2011: 10).

As participants in professional development activities, teachers and teacher educators play a dual role, as teachers remain educators who will transfer their newly acquired knowledge and skills to their learners, but also assume the learners' role by acquiring new skills (Beavers, 2009: 26). Similarly, teacher educators face a paradox in the sense that their role as teacher educators demands a focus on knowledge about teaching and learning, while they remain aware that the knowledge they bring, which is often based on personal experiences and activities, cannot simply be transferred to the thinking and experiences of their participants (Berry, 2009: 306). Malcolm Knowles' (1968) description of andragogy - in which he emphasises that adult learners have preconceived ideas for what and how they need to learn based on existing knowledge and previous experiences (Merriam \& Brockett, 2011) - can be considered as a means to overcome this paradox. Considering existing experiences, it would make sense to propose enabling teachers to play a more active role in their professional development by fostering self-directed learning (SDL) among South African teachers in general, and German Second Additional Language (SAL) teachers in particular, so as to overcome challenges posed to their professional development. For these purposes, the article initially investigates and defines the expectations placed on South African teachers in general and considers the challenges placed on German SAL teachers by policies governing the teaching and learning of SALs in South Africa. The article then strives to motivate the need for a professional development programme fostering SDL as a possible solution to the existing developmental shortcomings.

As is demonstrated by Van der Walt (2016: 3), research into SDL might be seen as focusing on three major categories, namely: research into the 'self', which focuses on the individuality of the learner; research into the 'directedness' of the learner, which focuses on purposefulness; and research into the 'learning' itself. While by no means exhaustive, a list of examples of such research is provided in Table 1. 
Table 1: Research on self-directed learning

\begin{tabular}{|l|l|}
\hline Self & Topic \\
\hline Author & Learning effectiveness and student satisfaction \\
\hline Banerjee (2011) & Self-directed learning readiness \\
\hline Guglielmino (1978) & Dimensions of the self-directed learner \\
\hline Long (2000) & $\begin{array}{l}\text { Effects of learning strategies on self-directed learning } \\
\text { skills }\end{array}$ \\
\hline Directed & Fostering self-directed learning \\
\hline Bagheri et al. (2013) & $\begin{array}{l}\text { Learner's actions to master making decisions regarding } \\
\text { learning material }\end{array}$ \\
\hline Teo \& Lee (2010) & Management phases of the self-directed learner \\
\hline Knowles (1975) & \multicolumn{2}{|l|}{} \\
\hline Thornton (2010) & $\begin{array}{l}\text { Learner action in and perceptions of self-directed } \\
\text { learning }\end{array}$ \\
\hline Learning & $\begin{array}{l}\text { Relationship between self-directed readiness factors and } \\
\text { learning outcomes }\end{array}$ \\
\hline Lee et al. (2014) &
\end{tabular}

For the purposes of this article, emphasis is placed on the first two aspects, namely 'self' and 'directed' - fostering the characteristics of a self-directed learner in teachers as active participants in professional development programmes. Fostering the characteristics of SDL in teachers would follow suit of international developments in teacher professional development that have shown a move away from the traditional in-service teacher training model towards the acceptance that teacher development is a complex process which combines a multitude of internal as well as external factors (Avalos, 2011: 17). Participants are now actively viewed as unique learners (Beavers, 2009: 28). This implies that teachers are not only seen as members of a workforce needing upskilling (Smith, 2017b: v), but also as active co-creators of knowledge. This shift is shown in the research of various authors: Berry (2009), who explained that many teacher educators themselves are successful teachers with high levels of self-awareness and self-understanding; Girvan et al. (2016), who used reflections to study teachers' experiences in experiential learning; or Ermeling (2010), who traced the effects of collaborative inquiry on individual classroom practice, to name but a few examples.

In an attempt to narrow the gap between theoretical requirements set to teachers, which will be elaborated on later in this article, and teaching practice in classrooms, this article takes the form of a critical literature review, considering not only existing literature on SDL and teacher development, but also relevant government policies outlining regulations regarding the teaching and learning of SALs as well as general professional development requirements set to teachers. There is, therefore, a strong theoretical focus supplemented by a document analysis of the identified relevant policies. The article seeks to propose that fostering SDL characteristics in South African teachers might greatly assist these teachers in taking responsibility for their professional development. For these purposes, policy documents on the education and training of South African teachers are considered so as to establish the educational and developmental expectations placed on South African teachers. Thereafter, challenges faced by South African teachers, and German SAL teachers in particular, are highlighted. Finally, recommendations regarding teacher professional development are made 
as were drawn from theories of SDL. In this regard, it is proposed that certain characteristics fostering SDL, which are described in the article, be cultivated in teachers to aid these professionals to attain their own developmental goals.

\section{TEACHER PROFESSIONAL DEVELOPMENT IN SOUTH AFRICA}

In order to establish how value-laden the teaching profession is and how much pressure rests on teachers, it would seem relevant to define a teacher and what values are attached to the profession. A cursory survey of the various definitions of teacher yielded varied and disparate results. While Gabela (2004: 55) views a teacher as a specialised person who has undergone a rigorous and relevant education programme, the South African Department of Basic Education (2005: 6) sets specific standards in its definition of the term:

[A teacher is] a person with the educated competences and abiding commitments needed to engage successfully in the professional practice of teaching. A professional teacher is characterised more by a commitment to the ideals of the profession, and flexible competences to pursue those ideals in a variety of circumstances, than by mere obedience to the legitimate requirements of an employer.

In this definition, a commitment to the ideals of an educator and the competence to pursue those ideals seem to stand out in defining a teacher as a person not only committed to teaching but also to lifelong learning (Bolhuis, 2003: 328) in an attempt to keep up to date with changing requirements set to teachers and learners alike. The Department of Basic Education, in Goal 16 of the Action Plan 2014: Realisation of Schooling 2025 (DoBE, 2011a: 107) expressly requires teachers to remain lifelong learners, as it regards teaching as an ongoing learning process and requires that teachers' professionalism, teaching skills and subject knowledge are improved upon throughout their careers so that they can equip their learners with the knowledge and skills required for their respective learning levels (DHET, 2015: 10). This focus on lifelong learning implies a degree of self-direction in terms of taking charge of one's own learning and setting specific outcomes (Knowles, 1975: 18).

However ideal these theoretical requirements set for teachers in South Africa seem, popular media blames learners' low literacy levels on under-qualified teachers (Hawker, 2013; Savides, 2017; Silva, 2017). Furthermore, reports such as the PIRLS 2016 (Progress in International Reading Literacy Study) found that $60 \%$ of participating South African schools experienced problems with the absenteeism of teachers and failure to complete the curriculum (Howie et al. 2017: 8), This situation gives rise to the belief that the set requirements are not met in practice. Upon closer investigation of national and international reports on literacy in South Africa, it becomes apparent that there does indeed seem to be a crisis in the South African education system. This crisis is especially severe in rural areas, as is indicated in the Annual National Assessments Report (DoBE, 2014: 11). Similarly, in a report commissioned by the Centre for Development and Enterprise, Spaull (2013b: 10) comes to the conclusion that the South African education system is in an ongoing crisis and is failing the South African youth. He bases this claim on findings like those of the Western Cape Learner Assessment Study (Taylor et al., 2008: 43) and the National School Effectiveness Study (Taylor, 2011). Unfortunately, even though these findings are largely focused on learners at primary school level, the situation does not seem to improve at higher education levels, as is demonstrated by authors such as Van Dyk and Van de Poel (2013: 44) and Dreyer and Nel 
(2003: 349), who found in their research that first-year university students enter university with sub-par literacy levels.

German SAL teachers, which is the specific context of this research, face the additional challenge that, in the South African schooling system, the subject German as Foreign Language is currently regulated by the Language in Education Policy, 1997: 1) as a SAL. The CAPS (DOBE, 2011b: 12) assumes 'that learners do not necessarily have any knowledge of the language when they arrive at school. The focus upon exposure to Second Additional Language is on developing learners' ability to understand and speak the language - basic interpersonal communication skills.' While theoretically allowing for SALs to be taught from Grade 4, '[s]chools offering an optional language or at least Second Additional Language level may do so [only] if they can make an arrangement for the allocation of additional time to the allocated 27.5 hours' (DOBE, 2011b: 8). The CAPS (DOBE, 2011b: 7) goes even further, instructing that ' $[\mathrm{t}]$ he allocated time per week may be utilised only for the minimum required $\mathrm{NCS}^{1}$ subjects as specified above, and may not be used for any additional subjects added to the list of minimum subjects. Should a learner wish to offer [sic] additional subjects, additional time must be allocated for the offering of these subjects. ${ }^{2}$ In practice, this translates to teachers having to offer SALs outside of regular school hours, either early in the morning or in the afternoon, while having to teach other subjects during regular school hours. This puts German SAL teachers under great time constraints, which have the potential to be a major obstacle to these teachers' professional development.

While teachers cannot be held solely responsible for low literacy and achievement rates which seem to be exacerbated by factors like poverty levels, low parental literacy rates, poor school governance, and lack of resources (Pretorius \& Klapwijk, 2016: 2) - teachers do play a leading role in providing learners with knowledge, skills and understanding of the subject matter at hand (Arkoudis, 2003: 162; Webb, 2009). Short (2002: 18) concurs and argues that learners are far more probable to achieve academic success if teachers have received adequate training. It therefore seems imperative for a country to have highly qualified teachers if learners are to achieve success (Christ, 2002: 51; Bransford et al., 2005: 31).

According to the National Qualifications Framework Act (67/2008): Revised policy on the minimum requirements for Teacher Education Qualifications (DHET, 2015), the four-year Bachelor of Education (BEd) degree and the professionally-focused Postgraduate Certificate in Education (PGCE) are the two official Initial Teacher Education Programmes (ITEs). ${ }^{3}$ German SAL teacher training should be viewed in this context. While the policy makes provision for universities, as well as for private higher education institutions to be accredited to conduct teacher training (DHET, 2015: 58), only Stellenbosch University and the University of Pretoria currently provide German SAL teacher training (Mbohwa-Pagels \& Rode, 2014: 16). After completing their qualification (BEd or PGCE), aspiring teachers have to adhere to minimum requirements for teacher education as set by the Department of Higher Education and Training in its Policy on Minimum Requirements for Teacher Education Qualifications (MRTEQ) (DHET, 2011: 10). Minimum requirements set for entry-level

\footnotetext{
${ }^{1}$ National Curriculum Statement

${ }^{2}$ In the reading of this quote, the interpretation of Mbohwa-Pagels and Rode (2014) is followed. It is assumed that schools are only allowed to offer additional subjects outside regular school hours.

${ }^{3}$ While the Policy does make provision for alternative qualification routes like Recognition of Prior Learning (DHET, 2015: 14) and Work Integrated Learning (DHET, 2015: 15), the BEd and the PGCE remain the required formal qualifications.

Per Linguam 2019 35(3):125-142
}

http://dx.doi.org/10.5785/35-3-870 
teachers are reiterated in the National Qualifications Framework Act (67/2008): Revised policy on the minimum requirements for Teacher Education Qualifications. According to these policies, teachers must display sound subject knowledge, didactical and interpersonal competencies, highly developed communicative, literacy, numeracy and information technology (IT) skills and a sound knowledge of the curriculum and how to implement it. Furthermore, entry-level teachers are also expected to embrace diversity, have sound knowledge of assessment types and criteria, and have a positive work ethic (DHET, 2015: 64).

However, as was mentioned earlier, the National Qualifications Framework Act (67/2008): Revised policy on the minimum requirements for Teacher Education Qualifications (DHET, 2015: 8) makes it clear that remaining a competent teacher is an ongoing learning process. Point 11 of the Set of Basic Competencies of a Beginner Teacher (DHET, 2015: 64) clearly states the emphasis put on lifelong learning expected from teachers: 'Newly qualified teachers must be able to reflect critically on their own practice, in theoretically informed ways and in conjunction with their professional community of colleagues in order to constantly improve and adapt to evolving circumstances.'

While the abovementioned stipulation refers to newly qualified teachers, it needs to be kept in mind that experienced teachers are also required to work on furthering their education (Robinson, 2003: 20). Should a teacher, in an attempt to adhere to this requirement, wish to further his/her formal qualifications, he/she can partake in formal, qualification-based Continuing Professional Development (CPD) learning programmes (DHET, 2015: 33). However, even if the teacher does not elect to further his/her official qualifications, he/she is required to reach at least 150 professional development (PD) points every three years (SACE, 2013: 8), as is determined by the teacher's personal Professional Development Portfolio (PDP) (SACE, 2013: 5), and is set out in the South African Council for Educators' (SACE) Continuing Professional Teacher Development (CPTD) Management System (SACE, 2013). Points may be accrued by activities initiated by the teacher (Type 1), by the school (Type 2) (SACE, 2013: 9), or by an external provider endorsed by SACE (Type 3) (SACE, 2013: 10). Teachers are required to participate in all three types of PD activities in a three-year cycle. This ties in closely with the requirement set in the National Qualifications Framework Act (67/2008): Revised policy on the minimum requirements for Teacher Education Qualifications (DHET, 2015: 60) for teachers to remain lifelong learners. The document clearly requires that ' $[\mathrm{t}]$ he educator will achieve ongoing personal, academic, occupational and professional growth, through pursuing reflective study and research in their chosen field, in broader professional and educational matters and in other related fields.' (DHET, 2015: 61)

Based on the previously mentioned requirement of the National Qualifications Framework Act (67/2008): Revised policy on the minimum requirements for Teacher Education Qualifications (DHET, 2015: 61), one can, therefore, deduce that lifelong learning is not only limited to official PDP activities. In addition to working on their own PDP targets, teachers are also required to participate in the Integrated Quality Management System (IQMS), which appraises individual educators in regard to their strengths and weaknesses. Therefore, while continually improving their skills by means of PDP activities, teachers are also expected to be appraised and evaluated by the IQMS. This system was negotiated with teacher unions in the Education Labour Relations Council (ELRC) and signed as the ELRC Collective Agreement No. 8 of 2003 (DoBE, 2011c: 73). The implementation of the IQMS can possibly be lauded for introducing a transparent, educator-initiated appraisal system, for which school 
management and district officials are accountable (De Clerq, 2008: 13). However, while the IQMS was devised as a mechanism to appraise development, measure performance and evaluate whole schools, it has been criticised as being bureaucratic, time-consuming and involving too much paperwork (DoBE, 2011c: 13). Possibly as a result of teachers' and schools' resistance against the IQMS, only $13 \%$ of 10969 schools visited in February 2010 by the Teacher Development Summit had actually fully implemented the IQMS (DoBE, 2011c: 74). De Clerq (2008: 13) further elaborates on the shortcomings of the IQMS, highlighting its unrealistic assumptions regarding teachers' work, status and competences, and the awkwardness of one system of internal and external professional monitoring that leads to tensions as well as poor leadership at both district and school level.

Notwithstanding the challenges faced by teachers and policymakers, both educators and academics currently have a growing interest in teacher professional development measures (Johnson et al., 2000: 179). At the core of these teacher development measures and studies thereof, is the belief that professional teacher development is about teachers' further learning, teachers discovering how to learn and teachers translating this theoretical knowledge into practice for their students' benefit (Avalos, 2011: 10). However, it is imperative that any teacher development measures are based on South African teachers' specific development needs (Johnson et al., 2000: 180). This is furthermore illustrated by Mokhele and Jita (2010: 1763), who found in a study amongst teachers in Mpumalanga that much resistance to existing CPD programmes can be accredited to the fact that these programmes fail to take into account the individual reasons for teachers to participate in CPD activities as well as the processes that facilitate change in teachers. One could, therefore, deduce that it is crucial for CPD programmes and activities to be more individualised, considering teachers' individual backgrounds and education needs, as is discussed in the next section.

\section{THE NEED TO ENHANCE SELF-DIRECTED LEARNING IN TEACHER PROFESSIONAL DEVELOPMENT}

In the previous section, it was made clear that teacher professional development programmes are required by the National Qualifications Framework Act (67/2008): Revised policy on the minimum requirements for Teacher Education Qualifications (DHET, 2015: 60). The fact remains that the South African teaching population remains heterogeneous in their qualifications (Blommaert et al., 2005: 378) and development needs (DoBE, 2011c: 14), to which German SAL teachers form no exception, and that concerns about the shortcomings of existing teacher development programmes exist. This heterogeneity amongst teachers in combination with the speed at which new knowledge is generated (Guglielmino, 2008: 4) gives rise to the belief that an effective teacher development programme would have to be highly individualised if it is to motivate teachers to remain lifelong learners. However, unfortunately researchers like Smith (2017b: 6) too often still find that existing teacher development programmes seem to be designed with a one-size-fits-all approach, focusing on cost-efficiency rather than on teachers' real learning needs.

As was mentioned earlier, andragogy, as postulated by Knowles (1968; 1973), focuses strongly on lifelong learning in adults and takes adults' individual experiences into account. Knowles distinguishes andragogy from pedagogy with the four basic assumptions that as a person grows and matures, his/her self-concept changes (Knowles, 1973: 45), his/her experiences play a greater role in his/her learning (Knowles, 1973: 45) and his/her readiness to learn is increasingly determined by the developmental tasks necessary to fulfil his/her 
social role (Knowles, 1973: 46). In addition, Knowles states that an adult has a more problemcentred approach to learning than a child (Knowles, 1973: 47). Fostering the characteristics of SDL, with which andragogy is closely connected, would enable teacher educators to draw on teachers' existing knowledge, experiences and needs, while focusing on these teachers' often quite individual developmental tasks.

Self-directed learning (SDL) has been characterised as one of the fastest growing research areas of the past 40 years (Guglielmino, 2013: 2). While much research focuses on SDL as a personal attribute (Merriam, 2001; Guglielmino, 2008), Dehnad et al. (2014: 5185) maintain that SDL is a complex concept for which various definitions exist, of which Malcolm Knowles' definition is the most widely accepted one. Malcolm Knowles (1975: 18) defines SDL as '[...] a process in which individuals take initiative, with or without the help of others, in diagnosing their learning needs, formulating learner goals, identifying human and material resources for learning, choosing and implementing appropriate learning strategies, and evaluating learning outcomes'. A self-directed learner would, therefore, be able to take a certain amount of pedagogical control (Bouchard, 2009: 13). Fostering SDL in German SAL teachers would also imply that they direct their own learning. For example, this would permit them to plan their learning according to their own time schedules and learning requirements, allowing for existing time limitations. By taking responsibility for his/her own learning, the self-directed learner is able to take over certain tasks traditionally ascribed to the teacher (Garrison, 2000) by means of autonomous learning strategies (Bouchard, 2009: 14). While focusing largely on individual character traits, SDL, therefore, encompasses a process by means of which individuals are trained to take responsibility for their own learning by setting learning aims, controlling resources, and self-evaluating the achievement of their own learning aims (Knowles, 1975; Adeola \& Ngoitiama, 2006), which would enable transformative learning and ultimately promote emancipation of the learner from the teacher (Merriam, 2001). This furthermore implies that SDL learners have to be highly motivated (Garrison, 1997). As German SAL teachers are already willing to teach German SAL outside normal schooling hours in addition to a full teaching load, they may already be quite motivated and would, therefore, suit the profile quite well.

However, as important as the aforementioned individual character traits are to SDL, one has to keep in mind the importance of the learning environment and economic factors as well (Bouchard, 2009:17), which is illustrated by Brockett and Hiemstra (1991), who claim that a balanced and congruent socio-economic background should be able to encourage SDL in learners. This socio-economic factor is not only explained by sufficient access to resources (Smith, 2017a: 24), but also by access to and experience in electronic learning resources (Bouchard, 2009: 17) and the ability to utilise and synthesise new media, on the part of both the student and the instructor (Garrison, 2000). Furthermore, Garrison (1997) stresses the importance of contextual factors, not only sufficient resources, but also the setting of realistic learning goals, constructive feedback and a positive learning atmosphere, which are necessary to truly enable SDL. While, in 2014, 92\% of secondary schools were relatively wellresourced former Model C schools (Mbohwa-Pagels \& Rode, 2014: 16), only 46\% of German SAL teachers had departmental posts in 2013 and usually taught English and Afrikaans during normal school hours in addition to teaching German SAL ((Mbohwa-Pagels \& Rode, 2014: 16). The Goethe-Institut does have so-called Lehrmittelzentren (teaching material centres) available in most provinces, at which German SAL teachers can borrow materials at no charge, but only half of the German teachers are reported to have made use of these (Mbohwa-Pagels \& Rode, 2014: 18). In direct conversations about the reason for the under- 
utilisation of these resources, teachers reported that the centres are too far away for them to regularly visit as well as not knowing which materials are available. Even though these factors are not conducive to SDL, they do show the necessity for more self-directedness and a higher level of knowledge about available materials and opportunities.

Self-directed learning, which certain authors (Hiemstra, 2003; Guglielmino, 2008; Cooker \& Benson, 2013) view as the most natural form of learning, could offer teachers the benefit of learning based on their own professional identity and needs (Rodgers \& Scott, 2008: 732). Since SDL postulates individual freedom, responsibility and personal views (Savin-Baden \& Major, 2004), it would benefit teachers in that learning would empower them 'to become a free, mature, and authentic self' (Savin-Baden \& Major, 2004: 14). It would, therefore, seem plausible that, instead of offering training solely based on the acquisition of new knowledge, an effective training programme focuses on the enhancement of individual learning skills, as is propagated by Knowles (1975: 15):

We are entering into a strange new world in which rapid change will be the only stable characteristic [...] It is no longer realistic to define the purpose of education as transmitting what is known [...] The main purpose of education must now be to develop the skills of inquiry.

Developing aforementioned skills of inquiry would imply promoting SDL in terms of andragogy (Knowles, 1968: 351) to ensure that individual teachers' developmental needs are truly met. The development of these skills is discussed in the next section.

\section{RECOMMENDATIONS TOWARDS DEVELOPING SDL IN SOUTH AFRICAN TEACHERS}

For the purposes of a self-directed skills development programme, teachers would have to be actively involved in planning their own learning (Beavers, 2009: 27). Furthermore, the intricacies of the teaching practice, as well as the existing knowledge and experience that practising teachers can contribute to educational discourse, will have to be strongly considered when planning a professional development activity (Smith, 2017a: 5). These experiences should then be actively applied to current and relevant situations in order to produce good educational results (Trotter, 2006: 11).

By following the aforementioned bottom-up approach, teachers would be encouraged to take responsibility for their own learning (Tough, 1971; Knowles, 1975; Guglielmino \& Guglielmino, 2006) by defining their own learning needs. Therefore, the participants' selfdevelopment is the focus point of learning, and facilitators of teacher development programmes are working with, not on, teachers (Smith, 2017a: 6). To reformulate, teachers would have to be enabled to define their own learning needs, while the facilitator's role would be to assist teachers to find ways to fulfil these needs. The facilitator's primary role would, therefore, consist of preparing participants to engage in critical learning activities that would enable them to achieve their own developmental goals (Loyens et al., 2008: 414).

In order to achieve these aims, professional development programmes would, therefore, have to focus on fostering SDL by ensuring that South African teachers possess the characteristics of a self-directed learner. The most generally operable definition of such a learner is described by Guglielmino (1978: 73) in her Delphi survey of experts: 
A highly self-directed learner, based on the survey results, is one who exhibits initiative, independence, and persistence in learning; one who accepts responsibility for his or her own learning and views problems as challenges, not obstacles; one who is capable of self-discipline and has a high degree of curiosity; one who has a strong desire to learn or change and is self-confident; one who is able to use basic study skills, organise his or her time and set an appropriate pace for learning, and to develop a plan for completing work; one who enjoys learning and has a tendency to be goal-oriented.

While considering this definition, it becomes clear that readiness for SDL exists on a continuum, which differs amongst individuals, but which can be trained (Guglielmino, 2013: 3). Measuring and quantifying this readiness has been facilitated by Guglielmino's SDL Readiness Scale (SDLRS) (1978), which is still widely used today (Liddell, 2008: 16) and focuses on 11 characteristics of self-directed learners, including initiative, independence, persistence, responsibility, self-discipline, curiosity, desire (to learn or change), basic skills (study and organisational), pacing/completion, joy of learning, and goal orientation (Guglielmino, 1978). This scale can be supplemented by the self-rating scale of self-directed learning (SRSSDL) developed by Williamson (2007: 68), which adds to the SDLRS by assessing self-directed learning behaviour in addition to perceptions and readiness for selfdirected learning.

When considering the attributes of a self-directed learner, literature shows a combination of personality aspects and skills (Table 2).

Table 2: Personality aspects and skills required for self-directed learning

\begin{tabular}{|l|l|}
\hline Author & Characteristics \\
\hline Knowles (1975) & $\begin{array}{l}\text { Relate collaboratively to peers; see peers as resources for } \\
\text { diagnosing needs and planning learning; give help and receive } \\
\text { help from peers; diagnose own learning needs realistically, with } \\
\text { help from facilitators and peers; translate learning needs into } \\
\text { learning objectives; relate to educators as facilitators, and take } \\
\text { initiative in making use of their resources; identify human and } \\
\text { material resources; select effective strategies for making use of } \\
\text { learning resources; and collect and validate evidence of the } \\
\text { achievement of various kinds of learning objectives. }\end{array}$ \\
\hline Guglielmino (1978) & $\begin{array}{l}\text { Initiative; independence; persistence; sense of responsibility } \\
\text { for one's own learning; tendency to view problems as } \\
\text { challenges; self-discipline; high degree of curiosity; strong } \\
\text { desire to learn or change; ability to use basic study skills; } \\
\text { ability to organise one's time and set an appropriate pace for } \\
\text { learning; self-confidence; ability to develop a plan for } \\
\text { completing work; joy in learning; tolerance of ambiguity; } \\
\text { preference for active participation in shaping educational } \\
\text { programme; ability to evaluate one's own progress; exploratory } \\
\text { view of education; above-average risk-taking behaviour; } \\
\text { knowledge of a variety of potential learning resources and }\end{array}$ \\
\hline
\end{tabular}




\begin{tabular}{|l|l|}
\hline & $\begin{array}{l}\text { ability to use them; ability to accept and use criticism; ability to } \\
\text { discover new approaches for dealing with problems; ability to } \\
\text { formulate learning objectives; ability to select and use many } \\
\text { learning strategies; positive orientation to the future; emotional } \\
\text { security; average or above average intelligence; creativity; } \\
\text { preference for independent study or relatively unstructured } \\
\text { sources. }\end{array}$ \\
\hline Patterson et al. (2002) & $\begin{array}{l}\text { Assessment of learning gaps; evaluation of self and others; } \\
\text { reflection; information management; critical thinking; and } \\
\text { critical appraisal planning; }\end{array}$ \\
\hline $\begin{array}{l}\text { Wharnton (2010) } \\
(2013)\end{array}$ & $\begin{array}{l}\text { Moves through phases of management: plang } \\
\text { implementing; monitoring; evaluating; and reflecting }\end{array}$ \\
\hline $\begin{array}{l}\text { Asking appropriate questions to guide their inquiry; } \\
\text { interrogating the assumptions behind the ideas presented to } \\
\text { them; identifying appropriate resources and tools; and } \\
\text { strategically modifying these tools to achieve their learning } \\
\text { goals and Voles }\end{array}$ \\
\hline
\end{tabular}

When considering the abovementioned skills and characteristics of self-directed learners, it becomes apparent that much emphasis is placed on participants assessing their own learning needs and planning their own learning. As participants, teachers would, therefore, be given the opportunity to take responsibility for their own learning. Instead of following the traditional approach, whereby generic programmes are designed to achieve the most costeffective means of delivering information while also achieving the greatest outreach, teachers themselves would need to be the key decision makers about what matters to their own professional development (Smith, 2017a: 5). Instead of imparting knowledge to participants, the facilitator would enable them to develop the skills necessary to become lifelong, independent learners (Guglielmino, 2013: 5). Considering that about 50\% of German SAL teachers are non-mother tongue speakers, who have learned the language at universities, where German is no longer taught (Mbohwa-Pagels \& Rode, 2014: 15) and that German SAL teachers are often quite isolated in their schools with limited possibilities to practice their own language skills (Mbohwa-Pagels \& Rode, 2014: 16), it would make sense to consciously work with teachers' own needs and be aware of their difficult working situations, instead of imparting a top-down model devised by people who do not share the German SAL teachers' experiences.

In accordance to Patterson et al.'s (2002: 26) four-level Assessment of Learning Gaps table, teachers would initially identify gaps with the assistance of the facilitator (level 1) until gradually becoming 'independent and confident in identifying gaps through the integration of data from a variety of sources within a broader context of learning'. This increased confidence, in turn, would foster the personality attributes mentioned by Guglielmino (1978), which again, would enable them to learn more independently.

Teachers, as participants, would, therefore, learn to recognise their own existing skills and knowledge and accept themselves as major role players in their own development (Grow, 1991: 133), setting their own goals and standards (Grow, 1991: 134). As self-directed learners, they would also master critically evaluating their own learning (Patterson et al., 2002; Thornton, 2010) and modifying the tools and processes at their disposal to achieve their 
learning aims (Warburton \& Volet, 2013). In practice, a professional development programme focusing on fostering the characteristics of SDL could be represented as follows:

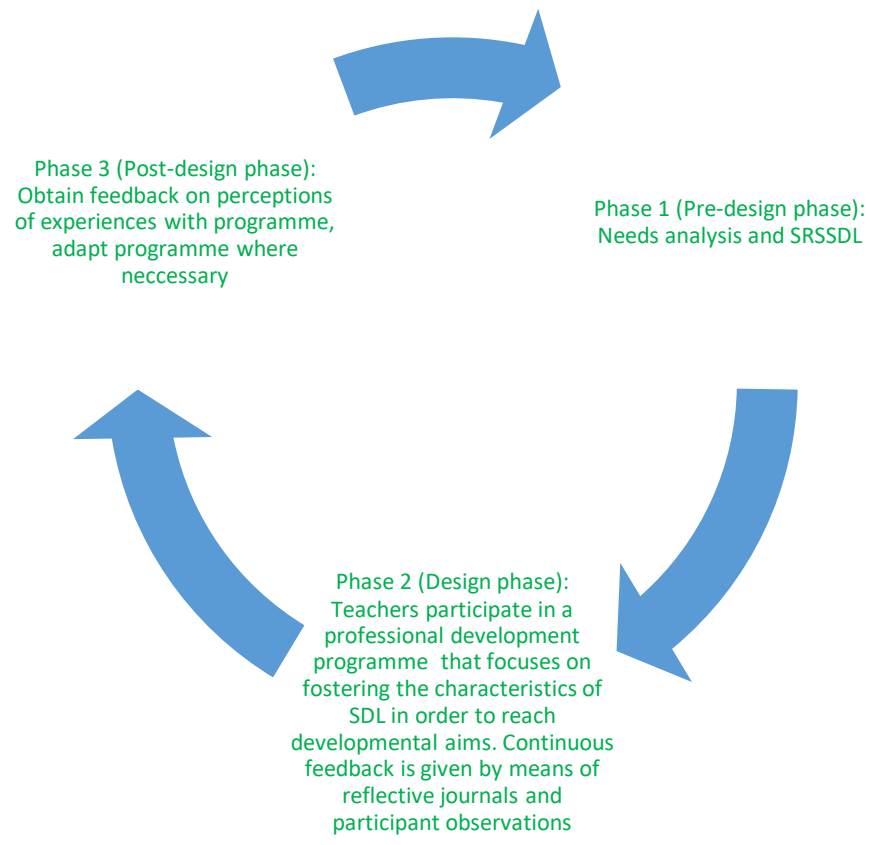

In Phase 2 of the model, professional development opportunities should be based on concrete classroom problems (Trotter, 2006: 12). This is in line with Knowles' assumption that adults have a problem-centred approach to learning (Knowles, 1973: 47). This would tie in closely with problem-based learning, an instructional method aiming to provide participants with the necessary knowledge to solve real problems (Schmidt, 1983: 11). While not much can be done about the fact that German SAL is not taught very widely in South Africa, it might be of assistance to German SAL teachers to form part of an online community of practice. Learning would be mediated (Avalos, 2011: 12) and take the form of collaborative learning (Murray et al., 2009; Ermeling, 2010) by dialogues, conversations and interactions with peers. Since the group of German SAL teachers in South Africa is quite small and teachers tend to know each other, this would enable horizontal sharing of ideas and experiences, which play a big role in collaborative learning. While retaining a focus on the individual's autonomy (Murray, 2014: 4) within a social setting (Cooker \& Benson, 2013: 17), participants would be enabled to work on solving their own problem-based learning aims (Loyens et al., 2008: 413) cooperatively (Loyens \& Gijbels, 2008). Throughout the programme, changes should be made as necessary and the programme should be re-evaluated continuously (Lynch, 1990: 36) to ensure that participants reach their learning aims and continue to determine their own learning. Such a horizontal learning approach has the potential to greatly assist teachers in overcoming other obstacles to their own learning, such as a lack of classroom resources (Johnson et al., 2000: 181) or isolation in their work environment (Jita \& Ndlalane, 2009: 63).

\section{CONCLUSION}

This article provided a brief overview of the policies relating to teacher professional development, the expectations placed on teachers, specific challenges placed on German SAL teachers by existing policies, and general developmental challenges faced by South African 
teachers. A brief definition of SDL was provided, and it was suggested that the values of SDL be fostered in teacher development programmes. In practice, implementing SDL in teacher development programmes would translate to teachers (as participants of the development programme) being enabled to define their own learning needs, after which they would collaborate with each other and the facilitator, finding ways to meet them. Thereafter, they would reflect on the processes they followed and make adaptations where necessary. Ideally, this approach would turn teachers into empowered learners who are inquisitive, enthusiastic, reflective and increasingly autonomous (Cannella \& Reiff, 1994: 28) and would be able to translate the new-found skills in their classroom, thereby inspiring their learners to become self-directed themselves. Such a programme would be especially suitable to German SAL teachers. While many challenges exist for effective teacher development (Aldridge et al., 2004: 245), SDL could possibly, or at least partly, be a way for teachers to overcome challenges (Mushayikwa \& Lubben, 2009: 376) by assisting them to recognise and develop their own problem-solving skills as well as by encouraging peer education and support.

\section{REFERENCES}

ADEOLA, A \& Z NGOITIAMA. 2006. Managing self-directed learning in African universities: the case of Nigeria and Botswana. Journal of Adult Education, Tanzania (14):59-85.

ALDRIDGE, JM, BJ FRASER \& MP SEBELA. 2004. Using teacher action research to promote constructivist learning environments in South Africa. South African Journal of Education, 24(4):245-253.

ARKOUDIS, F. 2003. Teaching English as a second language in Science classes: incommensurate epistemologies? Language and Education, 17(3):161 - 174.

AVALOS, B. 2011. Teacher professional development in teaching and teacher education over ten years. Teaching and Teacher Education, 27(1):10-20.

BAGHERI, M., WZW ALI, MCB ABDULLAH \& SM DAUD. 2013. Effects of projectbased learning strategy on self-directed learning skills of educational technology students. Contemporary Educational Technology, 4(1):15-29.

BANERJEE, G. 2011. Blended environments: Learning effectiveness and student satisfaction at a small college in transition. Journal of Asynchronous Learning Networks, 15(1):8-19.

BEAVERS, A. 2009. Teachers as learners: Implications of adult education for professional development. Journal of College Teaching \& Learning, 6(7):25-30.

BERRY, A. 2009. Professional selfunderstanding as expertise in teaching about teaching. Teachers and Teaching: theory and practice, 15(2):305-318.

BLOMMAERT, J, N MUYLLAERT, M HUYSMANS \& C DYERS. 2005. Peripheral normativity: Literacy and the production of locality in a South African township school. Linguistics and Education, 16(4):378-403.

BOLHUIS, S. 2003. Towards process-oriented teaching for self-directed lifelong learning: a multidimensional perspective. Learning and instruction, 13(3):327-347.

BOUCHARD, P. 2009. Pedagogy without a teacher: What are the limits. International Journal of self-directed learning, 6(2):13-22.

BRANSFORD, J, L DARLING-HAMMOND \& P LEPAGE. 2005. Introduction. In Darling-Hammond, L \& J Bransford (Eds.) Preparing teachers for a changing world what teachers should learn and be able to do. San Francisco Jossey-Bass.

BROCKETT, RG \& R HIEMSTRA. 1991. A conceptual framework for understanding 
self-direction in adult learning. Self-direction in adult learning: Perspectives on theory, research, and practice:18-33.

CANNELLA, GS \& JC REIFF. 1994. Individual constructivist teacher education: Teachers as empowered learners. Teacher Education Quarterly:27-38.

CHRIST, I. 2002. Die Ausbildung von Lehrkräften für Fremdsprachen und bilingualen Unterricht in der Sicht der Kultusverwaltungen. Fremdsprachen Lehren und Lernen, 31:42-63.

COLDWELL, M. 2017. Exploring the influence of professional development on teacher careers: A path model approach. Teaching and Teacher Education, 61:189-198.

COOKER, L \& P BENSON. 2013. The applied linguistic individual: Sociocultural approaches to identity, agency and autonomy. Sheffield: Equinox.

DE CLERQ, F. 2008. Teacher quality, appraisal and development: The flaws in the IQMS. Perspectives in Education, 26(1):7-18.

DEHNAD, A, F AFSHARIAN, F HOSSEINI, SKS ARABSHAHI \& S BIGDELI. 2014. Pursuing a Definition of Self-directed Learning in Literature from 2000-2012. Procedia-Social and Behavioral Sciences, 116:5184-5187.

DHET. 2011. Integrated strategic planning framework for teacher education and development in South Africa, 2011-2025. Department of Higher Education: Pretoria.

DHET. 2015. National Qualifications Framework Act (67/2008): Revised policy on the minimum requirements for teacher education qualifications. Government Gazette, 596(38487): Pretoria.

DOBE. 1997. Language in Education Policy in Terms of Section 3 (4) of the National Education Policy Act, 1996 (Act 27 of 1996). Department of Basic Education: Pretoria.

DOBE. 2011a. Action plan to 2014: Towards the realisation of schooling 2025: Department of Basic Education: Pretoria.

DOBE. 2011b. Curriculum and Assessment Policy Statement English as a Second Additional Language:8. Department of Basic Education: Pretoria.

DOBE. 2011c. Integrated Strategic Planning Framework for Teacher Education and Development in South Africa, 2011-2025: Technical Report: Department of Basic Education: Pretoria.

DOBE. 2014. Report on the Annual National Asssessment of 2014 Grades 1 to 6 \& 9. Department of Basic Education: Pretoria.

DOED. 2005. A national framework for teacher education in South Africa: Report of the Ministerial Committee on teacher education. Department of Education: Pretoria.

DREYER, C \& C NEL. 2003. Teaching reading strategies and reading comprehension within a technology-enhanced learning environment. System, 31(3):349-365.

ERMELING, BA. 2010. Tracing the effects of teacher inquiry on classroom practice. Teaching and Teacher Education, 26(3):377-388.

GABELA, RV. 2004. What makes a good teacher? In Balfour, R., T Buthelezi \& C Mitchell (Eds.) Teacher development at the centre of change. Durban: KZNDE Teacher development directorate. 55-57.

GARRISON, DR. 1997. Self-directed learning: Toward a comprehensive model. Adult Education Quarterly, 48(1):18-33.

GARRISON, R. 2000. Theoretical challenges for distance education in the 21st century: A shift from structural to transactional issues. The International Review of Research in Open and Distributed Learning, 1(1).

GIRVAN, C, C CONNEELY \& B TANGNEY. 2016. Extending experiential learning in teacher professional development. Teaching and Teacher Education, 58:129-139. 
GROW, GO. 1991. Teaching learners to be self-directed. Adult Education Quarterly, 41(3):125-149.

GUGLIELMINO, LM. 1978. Development of the self-directed learning readiness scale. Georgia: University of Georgia, Dissertation Abstracts International, 38.

GUGLIELMINO, LM. 2008. Why self-directed learning. International journal of selfdirected learning, 5(1):1-14.

GUGLIELMINO, LM. 2013. The case for promoting self-directed learning in formal educational institutions. SA-eDUC, 10(2): $1-18$.

GUGLIELMINO, PJ \& LM GUGLIELMINO. 2006. Culture, self-directed learning readiness, and per capita income in five countries. SAM Advanced Management Journal, 71(2):21.

HAWKER, D. 2013. Thousands of unqualified teachers are teaching SA children. Available from http://www.enca.com/south-africa/thousands-unqualified-teachers-sa-schools [Accessed: 21 August 2017].

HIEMSTRA, R. 2003. More than three decades of self-directed learning: From whence have we come? Adult Learning, 14(4):5-8.

HONG, JY. 2012. Why do some beginning teachers leave the school, and others stay? Understanding teacher resilience through psychological lenses. Teachers and Teaching, 18(4):417-440.

HOWIE, S, C COMBRINCK, K ROUX, M TSHELE, G MOKOENA \& NM PALANE. 2017. PIRLS 2016.

JITA, LC \& TC NDLALANE. 2009. Teacher clusters in South Africa: opportunities and constraints for teacher development and change. Perspectives in Education, 27(1):5868.

JOHNSON, S, M HODGES \& M MONK. 2000. Teacher development and change in South Africa: A critique of the appropriateness of transfer of northern/western practice. Compare: A Journal of Comparative and International Education, 30(2):179-192.

KNOWLES, MS. 1968. Andragogy, not pedagogy. Adult Leadership, 16(10):350-352.

KNOWLES, MS. 1973. The adult learner: a neglected species. Houston: Gulf Publishing Company.

KNOWLES, MS. 1975. Self-directed learning: A guide for learners and teachers. New York: Association Press.

LAM, D, C ARDINGTON \& M LEIBBRANDT. 2011. Schooling as a lottery: Racial differences in school advancement in urban South Africa. Journal of Development Economics, 95(2):121-136.

LEE, K, PS TSAI, CS CHAI \& JHL KOH. 2014. Students' perceptions of selfdirected learning and collaborative learning with and without technology. Journal of Computer Assisted Learning, 30(5):425-437.

LIDDELL, TN. 2008. Executive women's self-directed learning and leading in charitable foundations. International Journal of Self-Directed Learning, 5(1):15-29.

LONG, H. 2000. Understanding self-direction in learning. Practice and Theory in SelfDirected Learning:11-24.

LOYENS, SM. \& D GIJBELS. 2008. Understanding the effects of constructivist learning environments: Introducing a multi-directional approach. Instructional Science, 36(5):351-357.

LOYENS, SM., J MAGDA \& RM RIKERS. 2008. Self-directed learning in problembased learning and its relationships with self-regulated learning. Educational Psychology Review, 20(4):411-427. 
LYNCH, BK. 1990. A context-adaptive model for program evaluation. TESOL Quarterly:23-42.

MBOHWA-PAGELS, K. \& R RODE. 2014. DaF im SA Schulsystem eDusa, 9(1):13 - 19.

MENTZ, E. 2014. Mentz: Preparing pre-service teachers to support self-directed learning [Blog]. (Vol. 2018.): Washington: Partnership for 21st Century Skills.

MERRIAM, SB. 2001. Andragogy and self-directed learning: Pillars of adult learning theory. New Directions for Adult and Continuing Education, 2001(89):3-14.

MERRIAM, SB \& RG BROCKETT. 2011. The profession and practice of adult education: An introduction. San Francisco: John Wiley \& Sons.

MINOTT, MA. 2010. Reflective teaching as self-directed professional development: Building practical or work-related knowledge. Professional Development in Education, 36(1-2):325-338.

MODISAOTSILE, BM. 2012. The failing standard of basic education in South Africa. Policy Brief, 72:1-7.

MOKHELE, ML \& LC JITA. 2010. South African teachers' perspectives on continuing professional development: a case study of the Mpumalanga Secondary Science Initiative. Procedia-Social and Behavioral Sciences, 9:1762-1766.

MURRAY, G. 2014. Exploring the social dimensions of autonomy in language learning. Social dimensions of autonomy in language learning. London: Springer.

MURRAY, J. 2008. Towards the re-articulation of the work of teacher educators in Higher Education institutions in England. European Journal of Teacher Education, 31(1):1734.

MURRAY, S, X MA \& J MAZUR. 2009. Effects of peer coaching on teachers' collaborative interactions and students' mathematics achievement. The Journal of Educational Research, 102(3):203-212.

MUSHAYIKWA, E \& F LUBBEN. 2009. Self-directed professional development-Hope for teachers working in deprived environments? Teaching and Teacher Education, 25(3):375-382.

NEPAL, KP \& RA STEWART. 2010. Relationship between self-directed learningreadiness factors and learning outcomes in third year project-based engineering design course. In Proceedings of the 21st Annual Conference for the Australasian Association for Engineering Education organised by: Engineers Australia. 493.

ONO, Y \& J FERREIRA. 2010. A case study of continuing teacher professional development through lesson study in South Africa. South African Journal of Education, 30(1):59-74.

PATTERSON, C, D CROOKS \& O LUNYK-CHILD. 2002. A new perspective on competencies for self-directed learning. Journal of Nursing Education, 41(1):25-31.

PRETORIUS, EJ \& NM KLAPWIJK. 2016. Reading comprehension in South African schools: Are teachers getting it, and getting it right? Per Linguam: a Journal of Language Learning. Per Linguam: Tydskrif vir Taalaanleer, 32(1):1-20.

ROBINSON, M. 2003. Teacher education policy in South Africa: The voice of teacher educators. Journal of Education for Teaching, 29(1):19-34.

RODGERS, CR \& KH SCOTT. 2008. The development of the personal self and professional identity in learning to teach. In Cochran- Smith, M., Feiman-Nemser, S.D., Mcintyre, D.J. \& Demers, K.E. (Eds.). Handbook of Research on Teacher Education: Routledge/Taylor \& Francis Group and the Association of Teacher Educators.

SACE. 2013. The CPTD Management System Handbook. Available from 
https://sace.org.za/assets/documents/uploads/sace_30373-2016-08-31-

CPTD\%20Handbook.pdf [Accessed: 8 January 2019].

SAVIDES, M. 2017. South African schools have 5,139 teachers who are unqualified or under-qualified. Available from https://www.timeslive.co.za/news/south-africa/201706-06-south-african-schools-have-5139-teachers-who-are-unqualified-or-underqualified/ [Accessed: 21 August 2018].

SAVIN-BADEN, M \& CH MAJOR. 2004. Foundations of problem-based learning. Berkshire: SRHE \& Open University Press.

SCHMIDT, HG. 1983. Problem-based learning: rationale and description. Medical Education, 17(1):11-16.

SHORT, D. 2002. Language learning in sheltered Social classes. TESOL Journal, 11:18 24.

SILVA, B. 2017. Over 1700 unqualified teachers in South Africa. Available from http://westcapenews.com/?p=1431 [Accessed: 21 August 2018].

SMITH, K. 2017. Teachers As Self-directed Learners: Active Positioning through Professional Learning. Gateway East: Springer.

SPAULL, N. 2013a. Poverty \& privilege: Primary school inequality in South Africa. International Journal of Educational Development, 33(5):436-447.

SPAULL, N. 2013b. South Africa's education crisis: The quality of education in South Africa 1994-2011. Johannesburg: Centre for Development and Enterprise.

TAYLOR, N. 2011. The National School Effectiveness Study (NSES): Summary for the synthesis report. Johannesburg: JET Education Services.

TAYLOR, N, B FLEISCH \& J SCHINDLER. 2008. Changes in education since 1994. Background paper for the Fifteen Year Review of government business, commissioned by the Policy Unity, Office of the Presidency.

TEO, T \& C LEE. 2010. Fostering self-directed learning with ICT. ICT for Self-Directed and Collaborative Learning:39-51.

THORNTON, K. 2010. Supporting Self-Directed Learning: A Framework for Teachers1. Research and Practice in English Language Teaching in Asia:59.

TOUGH, AM. 1971. The Adult's Learning Projects: A Fresh Approach to Theory and Practice in Adult Learning. Michigan: Ontario Institute for Studies in Education.

TROTTER, YD. 2006. Adult Learning Theories: Impacting Professional Development Programs. Delta Kappa Gamma Bulletin, 72(2): 8-13.

VAN DER WALT, H. 2016. The Feasibility of Grafting Self-directed Learning Theory onto Capability Theory. In Mentz, E. \& Oosthuizen, I. (Eds.) Self-directed Learning Research. An Imperative for transforming the educational landscape. Cape Town: AOSIS.

VAN DYK, T \& K VAN DE POEL. 2013. Towards a responsible agenda for academic literacy development: considerations that will benefit students and society. Journal for Language Teaching. Ijenali Yekufundzisa Lulwimi. Tydskrif vir Taalonderrig, 47(2):43-69.

WARBURTON, N \& S VOLET. 2013. Enhancing self-directed learning through a content quiz group learning assignment. Active Learning in Higher Education, 14(1):9-22.

WEBB, NM. 2009. The teacher's role in promoting collaborative dialogue in the classroom. British Journal of Educational Psychology, 79(1):1-28.

WILLIAMSON, SN. 2007. Development of a self-rating scale of self-directed learning. Nurse Researcher, 14(2).

YAMAUCHI, F. 2011. School quality, clustering and government subsidy in post-apartheid South Africa. Economics of Education Review, 30(1):146-156. 


\section{BIBLIOGRAPHICAL NOTES}

Gerda-Elisabeth Wittmann is Subject Chairperson: German and a German lecturer at the North-West University. She is currently in the process of completing her PhD on Curriculum Development at the NWU's Faculty of Education and is active in various teacher professional development programmes for German SAL teachers.

Jako Olivier is a professor in Multimodal Learning in the Faculty of Education at the NorthWest University (NWU), South Africa. He holds the UNESCO Chair on Multimodal Learning and Open Educational Resources. His research, located within the NWU's Research Unit for Self-directed Learning, is focused on self-directed multimodal learning, open educational resources, multiliteracies, individualized blended learning, e-learning in language classrooms, online multilingualism and macro-sociolinguistics.

\footnotetext{
${ }^{\text {i }}$ For clarity's sake, the term facilitator is used in this article to refer to the person presenting the professional development activity, while teachers are deemed to be participants.
} 